\title{
PERAMALAN JUMLAH PENGUNJUNG PERPUSTAKAAN UNIVERSITAS PATTIMURA AMBON MENGGUNAKAN METODE DEKOMPOSISI
}

\author{
S. Yuni ${ }^{1}$, Mozart W. Talakua ${ }^{2}$, Yopi A. Lesnussa ${ }^{3}$ \\ 1,2,3 Jurusan Matematika FMIPA Universitas Pattimura \\ Jl. Ir. M. Putuhena, Kampus Unpatti, Poka-Ambon, Indonesia \\ e-mail: ${ }^{2}$ ocat_08@yahoo.com; ${ }^{3}$ yopi_a_lesnussa@yahoo.com
}

\begin{abstract}
Abstrak
Perpustakaan merupakan pusat informasi yang harus dikelola dengan baik agar dapat memberikan manfaat semaksimal mungkin. Penelitian ini bertujuan untuk mengetahui fluktuasi dan meramalkan banyaknya pengunjung Perpustakaan Universitas Pattimura (UNPATTI) Ambon menggunakan metode Dekomposisi. Data yang digunakan adalah data sekunder jumlah pengunjung perpustakaan UNPATTI sejak tahun 20112014 yang diperoleh dari perpustakaan UNPATTI. Prosedur penelitian dimulai dengan menganalisis komponen-komponen dekomposisi yaitu komponen trend $(T)$, musiman $(S)$, siklis $(C)$ dan komponen acak (I) kemudian mengalikan nilai dari komponen-komponen tersebut. Hasil prediksi menunjukkan bahwa jumlah pengunjung pada tahun 2015 bulan Januari sebesar 1337 pengunjung, Februari 2932 pengunjung, Maret 3640 pengunjung, April 3791 pengunjung, Mei 4333 pengunjung, Juni 2571 pengunjung, Juli 806 pengunjung, Agustus 920 pengunjung, September 968 pengunjung, Oktober 4187 pengunung, November 4495 pengunjung dan Desember 2960 pengunjung. Dapat dilihat bahwa jumlah pengunjung meningkat pada bulan Mei dan November.
\end{abstract}

Kata Kunci: Metode dekomposisi, perpustakaan, peramalan.

\section{FORECASTING THE NUMBER OF VISITORS AT THE LIBRARY OF PATTIMURA UNIVERSITY AMBON USING DECOMPOSITION METHOD}

\begin{abstract}
Library is an information center that must be managed properly in order to benefit as much as possible. This study aims to determine fluctuations and forecasting the number of visitors at the Pattimura University (UNPATTI) Library Ambon using Decomposition method. The data used are the secondary data of number visitors at UNPATTI library since 2011-2014 were obtained from the UNPATTI library. Research procedure begins by analyzing the components of the decomposition that is trend component $(T)$, seasonal $(S)$, cyclical $(C)$ and the random component $(I)$ and the multiplying the value of these components. Result of forecast showed that the number of visitors in 2015 amounted to 1337,77 visitors of January, 2932,99 visitors on February, 3640,31 visitors of March, 3791,00 visitors on April, 4333,90 visitors on May, 2571,11 visitors on June, 806,00 visitors on July, 920,15 visitors on August, 968,87 visitors on September, 4187,79 visitors on October, 4495,86 visitors November and 2960,10 visitors December. It can the seen that the number on visitors increased on March-May to September -November. One cause of this seasonal pattern of the data is in March-May to September-November is the time when a very active student is learning activities. Meanwhile, in July-August and December-January is the day of rest in college.
\end{abstract}

Keywords: Decomposition method, forecasting, library.

\section{Pendahuluan}

Perpustakaan yang terbentuk dari istilah librarius yang artinya tentang buku [1], yang mencakup suatu ruangan yang merupakan bagian dari gedung (bangunan) atau gedung tersendiri yang berisi buku-buku koleksi 
yang diatur dan disusun sedemikian rupa sehingga mudah untuk dicari dan dipergunakan apabila sewaktuwaktu diperlukan oleh pembaca. Perpustakaan merupakan pusat informasi yang dimana bahan-bahan perpustakaan dikumpulkan, diolah, disimpan, dan dipelihara untuk kemudian disebarluaskan agar dapat dimanfaatkan semaksimal mungkin oleh pengguna perpustakaan [2].

Kegiatan atau jasa utama perpustakaan adalah peminjaman buku dan materi lainnya sehingga salah satu tolak ukur keberhasilan perpustakaan adalah dengan tingkat pinjaman buku atau banyaknya kunjungan masyarakat (mahasiswa, dosen, dan tenaga pendidikan yang ada di lingkungan Universitas Pattimura) di perpustakaan. Pengelola perpustakaan (pustakawan) perlu mengetahui apakah masyarakat memahami pentingnya peranan perpustakaan dalam hal pendidikan. Untuk itu perlu dibuat suatu "ramalan". Ramalan yaitu memperkirakan sesuatu pada waktu yang akan datang berdasarkan data masa lampau yang dianalisa secara ilmiah, khususnya menggunakan metode statistik [3].

Pada penelitian ini digunakan model Deret Waktu (Time Series) yang merupakan bagian dalam peramalan kuantitatif. Dalam hal ini data masa lampau dikumpulkan, dipelajari dan dianalisis dihubungkan dengan perjalanan waktu yang hasilnya dapat menyampaikan sesuatu yang akan terjadi di masa yang akan datang. Dengan demikian seorang pustakawan yang bertanggung jawab penuh untuk mengetahui hasil peramalan akan naik atau turun banyaknya pengunjung tahun depan [4].

Dalam penelitian ini, metode dekomposisi digunakan untuk meramalkan jumlah pengunjung di Perpustakaan Universitas Pattimura Ambon. Metode dekomposisi (pemecahan) biasanya mencoba memisahkan 4 komponen (pola) perubahan. Komponen tersebut adalah faktor trend $(T)$, fluktuasi musiman $(S)$, fluktuasi siklus $(C)$, dan perubahan-perubahan yang bersifat acak atau random $(I)$. Keunggulan metode ini dalam peramalan adalah pola atau komponen-komponen tersebut dapat dipecah atau didekomposisi menjadi sub pola yang menunjukkan tiap-tiap komponen deret berkala secara terpisah dan pemisah tersebut seringkali membantu meningkatkan ketepatan dalam peramalan dan membantu atas deret data secara lebih baik [5]. Dalam penelitian ini, akan melihat fluktuasi pengunjung pada tahun 2011-2014 di Perpustakaan Universitas Pattimura Ambon serta prediksi banyaknya pengunjung perpustakaan pada tahun 2015.

\section{Tinjauan Pustaka}

Menurut Martika dalam [6], menyatakan bahwa langkah-langkah penggunaan metode Dekomposisi untuk forecasting yaitu :

a. Menyusun data bulanan masing-masing tahun.

b. Membuat scatter diagram garis trend linier.

c. Menghitung besarnya nilai trend.

\subsection{Metode Dekomposisi}

Metode dekomposisi termasuk pendekatan peramalan yang tertua. Metode ini digunakan pada awal abad ke-20 oleh para ahli ekonomi untuk mengenali dan mengendalikan siklus ekonomi dan bisnis. Dasar dari metode dekomposisi saat ini muncul pada tahun 1920-an ketika konsep rasio (trend) diperkenalkan.

Metode dekomposisi merupakan suatu metode peramalan yang menggunakan empat komponen utama dalam meramalkan nilai masa depan. Keempat komponen tersebut antara lain trend, musiman, siklus dan error. Metode dekomposisi dilandasi oleh asumsi bahwa data yang ada merupakan gabungan dari beberapa komponen, secara sederhana digambarkan sebagai berikut:

Data $=$ Pola + error

$$
=f(\text { trend }, \text { siklus, musiman })+\text { error }
$$

Asumsi di atas artinya terdapat empat komponen yang mempengaruhi suatu deret waktu, yaitu tiga komponen yang dapat diidentifikasi karena memiliki pola tertentu, yaitu: trend, siklus dan musiman. Persamaan umum matematis dari pendekatan dekomposisi adalah:

$$
X_{t}=f\left(T_{t}, S_{t}, C_{t}, I_{t}\right)
$$


dimana:

$X_{t}=$ nilai deret berkala (data aktual) pada periode $t$;

$T_{t}=$ komponen trend $($ trend $)$ pada periode $t$;

$S_{t}=$ komponen musiman (seasonal) pada periode $t$;

$C_{t}=$ komponen siklus (cyclic) pada periode $t$;

$I_{t}=$ komponen kesalahan tidak beraturan (irregular) pada periode $t$;

$t=$ periode (time) .

Dalam metode dekomposisi terdapat model dekomposisi aditif dan multiplikatif. Model dekomposisi aditif dan multiplikatif dapat digunakan untuk meramalkan faktor trend, musiman dan siklus. Metode dekomposisi rata-rata sederhana berasumsi pada model aditif yang secara matematis dapat ditulis:

$$
Y_{t}=T_{t}+S_{t}+C_{t}+I_{t}
$$

sedangkan metode dekomposisi pada data bergerak (dekomposisi klasik) berasumsi bahwa pada model multiplikatif yang secara matematis dapat ditulis:

$$
Y_{t}=T_{t} \cdot S_{t} \cdot C_{t} \cdot I_{t}
$$

\subsection{Gerak Musim dan Indeks Musiman}

Gerakan musim merupakan gerakan yang teratur dalam arti naik-turunya terjadi pada waktu-waktu yang sama atau sangat berdekatan. Disebut gerakan musim karena mempunyai pola tetap atau berulang-ulang secara teratur. Gerakan lainnya terjadi secara teratur dalam waktu yang singkat juga disebut gerakan musiman.

Untuk keperluan analisis, seringkali data runtun waktu dinyatakan dalam bentuk angka indeks. Indeks musiman merupakan angka yang menunjukkan nilai relatif variabel $Y$, dimana $Y$ adalah data deret waktu selama seluruh bulan dalam satu tahun (dapat lebih dari satu tahun). Rata-rata angka indeks musiman untuk satu periode adalah 100\% (tanda \% sering dihilangkan atau tidak ditulis). Dengan kata lain indeks musiman adalah suatu angka yang bervariasi terhadap nilai dasar 100.

Ada beberapa metode yang digunakan untuk menghilangkan angka indeks musiman, antara lain:

a. Metode rata-rata sederhana data yang ada dicari rata-rata bulanan untuk seluruh tahun, maksudnya angka rata-rata dipakai untuk mewakili bulan Januari, Februari, Maret - Desember.

b. Metode rasio terhadap trend data asli untuk setiap bulan dinyatakan sebagai presentase dari nilai-nilai trend bulanan.

\subsection{Data Runtut Waktu (Time Series)}

Data time series merupakan data yang dikumpulkan, dicatat atau diobservasi sepanjang waktu secara berurutan. Periode waktu observasi dapat berbentuk tahun. Time series dianalisis untuk menemukan pola variasi masa lalu yang dapat dipergunakan untuk memperkirakan nilai masa depan dan membantu dalam membuat perencanaan.

Analisis time series dipelajari karena dengan mengamati data time series akan terlihat empat komponen yang mempengaruhi suatu pola data masa lalu dan sekarang. Empat komponen yang mempengaruhi suatu pola tersebut, antara lain: Trend, Siklus, Musiman (seasonal), Error (Indeks Gerak Tak Beraturan).

\subsection{Penyelidikan Pola Data dengan Analisis Autokorelasi}

Observasi pada periode waktu yang berbeda sering berhubungan atau berkorelasi. Ukuran yang digunakan dalam korelasi adalah koefisien autokorelasi. Paket komputer MINITAB dapat digunakan untuk menghitung autokorelasi dan menghasilkan korelogram. Korelogram atau fungsi autokorelasi adalah grafik autokorelasi untuk lag yang bervariasi pada suatu waktu. Fungsi autokorelasi dikontruksikan dengan menggunakan MINITAB menghasilkan dua garis putus-putus menunjukkan pendekatan dengan tingkat kepercayaan 95\%. Ljung-Box $Q$ (LBQ pada MINITAB) misalnya dalam pemeriksaan, MINITAB mencatat 
bahwa autokorelasi untuk waktu pertama ketiga perbedaanya signifikan dari no1, $(0.96,0.92$ dan 0.87$)$ dan bahwa nilai itu berangsur-angsur turun menuju ke nol, maka dapat disimpulkan bahwa data berpola trend.

\subsection{Ukuran Ketepatan Peramalan}

Jika $X_{i}$ merupakan data aktual periode $i$ dan $F_{i}$ merupakan ramalan maka ukuran kesalahan didefinisikan sebagai berikut:

$$
e_{i}=X_{i}-F_{i}
$$

dimana:

$$
\begin{aligned}
& e_{i}=\text { kesalahan periode } i \\
& X_{i}=\text { data aktual untuk periode } i \\
& F_{i}=\text { ramalan (nilai kecocokan atau fitted value) untuk periode } i
\end{aligned}
$$

Jika terdapat nilai pengamatan di ramalan untuk $n$ periode waktu, maka akan terdapat $n$ buah galat dan ukuran statistik standar dapat di definisikan sebagai berikut:

$$
M S E=\frac{1}{n} \sum_{t=1}^{n}\left(e_{i}\right)^{2}
$$

Adapun ukuran-ukuran ketepatan yang sering digunakan untuk mengetahui ketepatan suatu metode peramalan dalam memodelkan data deret waktu adalah sebagai berikut:

a. MAPE (Mean Absolute Percentage Error) merupakan ukuran ketepatan relatif yang digunakan untuk mengetahui presentese penyimpangan hasil peramalan.

b. MAD (Mean Absolute Devotion) menyatakan penyimpangan ramalan dalam unit yang sama pada data, dengan merata-ratakan nilai absolute error (penyimpangan seluruh hasil).

c. MSD (Mean Square Devotion) merupakan ukuran penyimpangan ramalan dengan merata-ratakan kuadrat error (penyimpangan semua ramalan).

Dalam fase peramalan penggunakaan MSD dan MAD sebagai suatu ukuran ketepatan peramalan dapat menimbulkan masalah, karena MSD dan MAD merupakan ukuran absolute yang sangat bergantung pada skala dari data deret waktu. Karena alasan tersebut, maka dipakailah alternatif sebagai salah satu indikasi ketepatan dalam peramalan yaitu menggunakan MAPE.

\section{Hasil dan Pembahasan}

Perpustakaan Universitas Pattimura Ambon merupakan perpustakaan pusat yang sudah melayani mahasiswa UNPATTI sejak berdirinya perpustakaan dari tahun 1958 sampai dengan sekarang. Dalam rentang selama hampir 57 tahun, sudah banyak mahasiswa UNPATTI yang memanfaatkan ruang perpuspustakaan sebagai ruang baca. Dari aktifitas kunjungan ini, maka sangat penting untuk meramalkan jumlah pengunjung perpustakaan. Berikut adalah langkah-lagkah yang dilakukan dalam peramalan jumlah pengunjung perpustakaan menggunakan metode dekomposisi:

\subsection{Data Jumlah Pengunjung Perpustakaan dari Tahun 2011-2014}

Banyaknya jumlah pengunjung perpustakaan Universitas Pattimura Ambon dari bulan Januari 2011Desember 2014 disajikan pada Tabel berikut: 
Tabel 1. Jumlah Pengunjung Perpustakaan dari Tahun 2011- 2014

\begin{tabular}{|c|c|c|c|c|}
\hline \multirow{2}{*}{ Bulan } & \multicolumn{4}{|c|}{ Jumlah Pengunjung Perpustakaan } \\
\cline { 2 - 5 } & $\mathbf{2 0 1 1}$ & $\mathbf{2 0 1 2}$ & $\mathbf{2 0 1 3}$ & $\mathbf{2 0 1 4}$ \\
\hline Januari & 1301 & 655 & 686 & 2110 \\
\hline Februari & 1002 & 1256 & 1486 & 2603 \\
\hline Maret & 2772 & 1692 & 1790 & 4014 \\
\hline April & 2740 & 2013 & 2103 & 2603 \\
\hline Mei & 2036 & 2201 & 2067 & 3015 \\
\hline Juni & 2101 & 1231 & 1290 & 1678 \\
\hline Juli & 923 & 381 & 359 & 1542 \\
\hline Agustus & 545 & 491 & 455 & 1801 \\
\hline September & 557 & 1019 & 405 & 1059 \\
\hline Oktober & 2642 & 1969 & 1663 & 2016 \\
\hline November & 3079 & 2051 & 2939 & 4304 \\
\hline Desember & 1489 & 1361 & 2470 & 3023 \\
\hline
\end{tabular}

Sumber : Data UPT. Perpustakaan 2011-2014.

\subsection{Plot Data Pengunjung Perpustakaan Universitas Pattimura Ambon}

Time Series Plot terhadap jumlah pengunjung perpustakaan Universitas Pattimura Ambon dari bulan Januari 2011-Desember 2014 dapat dilihat pada Gambar berikut:

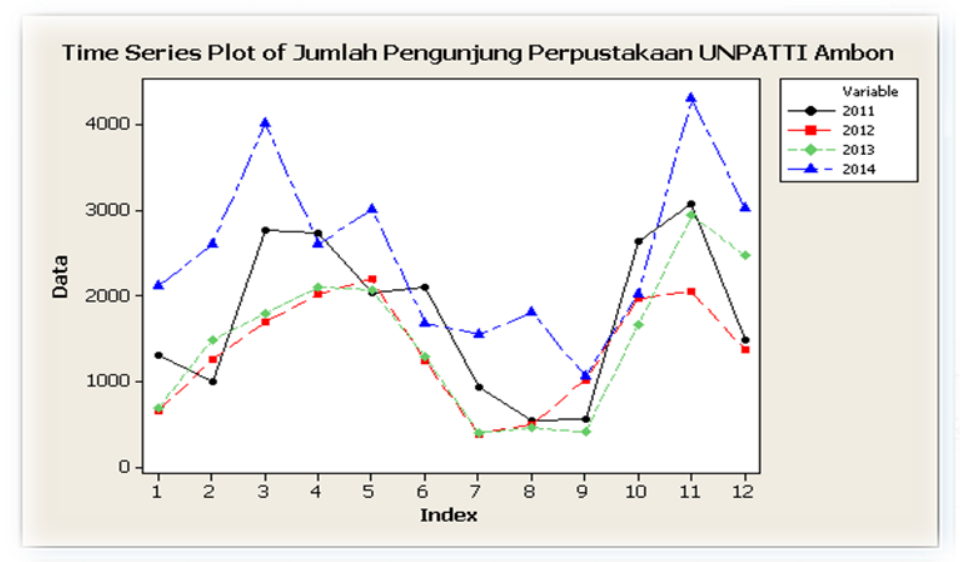

Gambar 1. Plot Data Jumlah Pengunjung Perpustakaan UNPATTI dari Tahun 2011-2014

Berdasarkan Gambar 1 di atas dapat dilihat bahwa pola time series berulang pada waktu tertentu. Rata-rata jumlah pengunjung meningkat pada bulan Maret, stabil hingga bulan Mei dan kembali mengalami penurunan pada bulan Juni-Agustus. Peningkatan terjadi lagi pada bulan September - November dan kembali menurun pada bulan Desember. Pola ini menunjukkan fluktuasi pola data time series musiman.

Untuk lebih jelasnya kita akan melihat dalam bentuk grafik Autocorrelation Function (ACF) dan Partial Autocorrelation Function (PACF) berikut ini: 


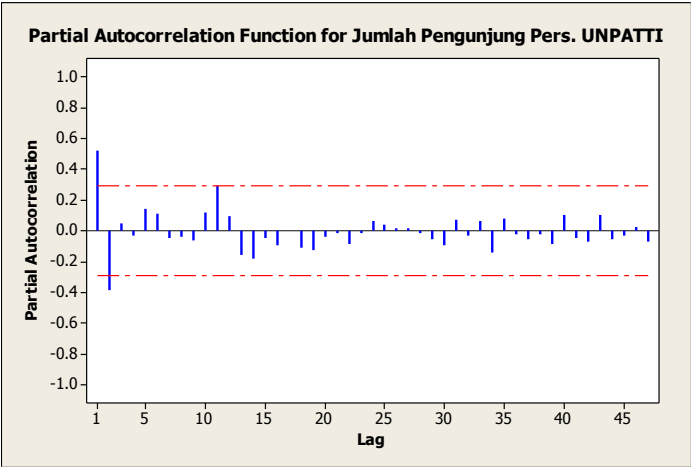

Gambar 2. Grafik ACF

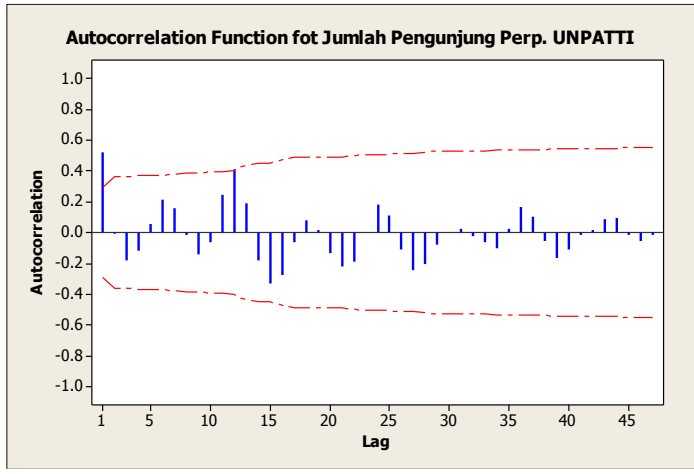

Gambar 3. Grafik PACF

Berdasarkan Gambar 2 dan Gambar 3 di atas dapat dilihat bahwa data runtun waktu (time series) tersebut merupakan trend karena pengamatan berturut-turut korelasinya tinggi, dan koefisien autokorelasi signifikan berbeda dari nol untuk beberapa lag waktu yang pertama dan kemudian berangsur-angsur turun mendekati nol.

\subsection{Prediksi menggunakan Metode Dekomposisi}

\section{a. Analisis Trend}

Berdasarkan analisis data menggunakan software MINITAB 14 diperoleh persamaan trend linier untuk data bulanan jumlah pengunjung yaitu: $Y_{t}=21256,25-10593,3 t$, dan diperoleh Gambar analisis Trend sebagai berikut:

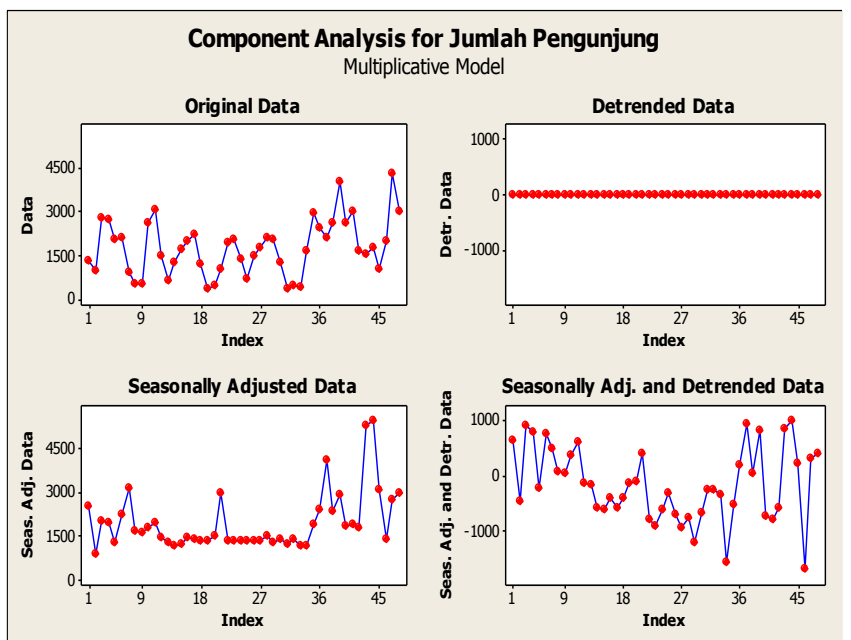

Gambar 4. Analisis Komponen Jumlah Pengunjung Perpustakaan UNPATTI

Berdasarkan Gambar 4 di atas memperlihatkan analisis komponen untuk data aktual (original data), data tidak trend (detrended data), penyesuaian data musiman (seasonally adjusted data) dan gabungan antara penyesuaian data musiman dan data tidak trend (seasonally adjusted and detrended data). 


\section{b. Analisis Musiman}

Dengan menggunakan software MINITAB 14 diperoleh Gambar analisis musiman sebagai berikut:

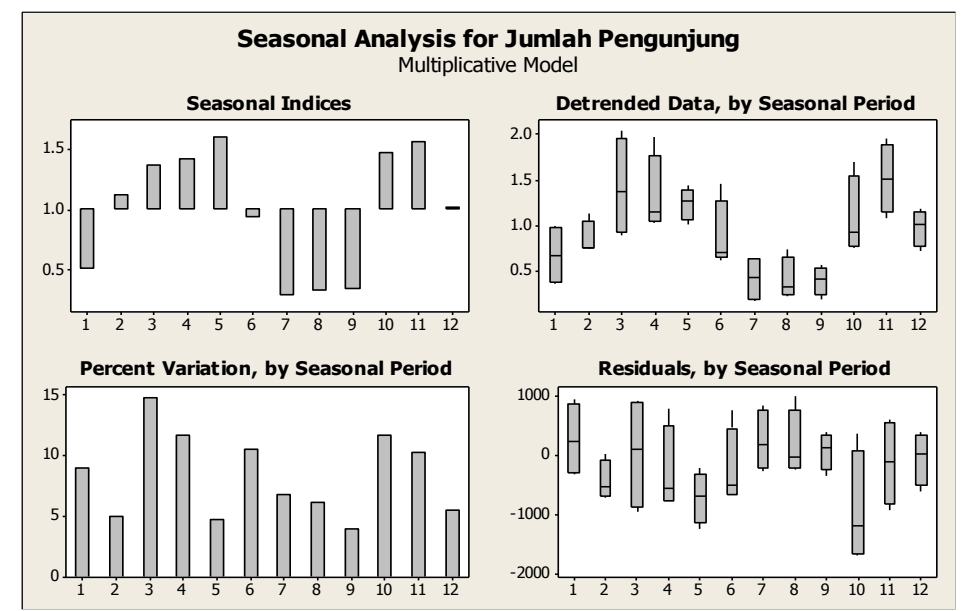

\section{Gambar 5. Analisis Musiman Jumlah Pengunjung Perpustakaan UNPATTI}

Pada Gambar 5 dapat dilihat analisis musiman, dimana rata-rata nilai indeks musim yaitu:

Periode $1: 0,51510=51 \%$ indeks musim pada bulan pertama.

Periode $2: 1,11775=111 \%$ indeks musim pada bulan kedua.

Periode $3: 1,37321=137 \%$ indeks musim pada bulan ketiga.

Periode $4: 1,41567=141 \%$ indeks musim pada bulan keempat.

Periode $5: 1,60229=160 \%$ indeks musim pada bulan kelima.

Periode $6: 0,94120=94 \%$ indeks musim pada bulan keenam.

Periode $7: 0,29217=29 \%$ indeks musim pada bulan ketujuh.

Periode $8: 0,33032=33 \%$ indeks musim pada bulan kedelapan.

Periode $9: 0,34448=34 \%$ indeks musim pada bulan kesembilan.

Periode 10: 1,47485 = 147\% indeks musim pada bulan kesepuluh.

Periode 11: 1,56987 $=156 \%$ indeks musim pada bulan kesebelas.

Periode 12: 1,02308 $=102 \%$ indeks musim pada bulan kedua belas.

Analisis musiman menunjukkan bahwa indikasi musiman memiliki nilai harapan sebesar $100 \%$ dan hasil yang kita dapat adalah jumlah pengunjung pada bulan pertama adalah $49 \%$ di bawah nilai harapan, bulan kedua adalah $11 \%$ di atas nilai rata-rata, bulan ketiga $37 \%$ di atas nilai rata-rata, bulan keempat $41 \%$ di atas nilai rata-rata, bulan kelima $60 \%$ di atas nilai rata-rata, bulan keenam $6 \%$ di bawah nilai rata-rata, bulan ketujuh $71 \%$ di bawah nilai rata-rata, bulan kedelapan juga $67 \%$ di bawah nilai rata-rata, bulan kesembilan $66 \%$ di bawah nilai rata-rata, bulan kesepuluh $47 \%$ di atas nilai rata-rata, bulan kesebelas $56 \%$ di atas nilai rata-rata dan bulan kedua belas $2 \%$ di atas rata-rata. Jadi dapat dilihat bahwa bulan kelima memiliki pola musiman yang paling tinggi yaitu 160\%, lebih besar $60 \%$ dari indeks musim yang diharapkan. Sedangkan bulan ketujuh, kedelapan, dan kesembilan merupakan indeks musim terendah dengan nilai sebesar $29 \%$, lebih kecil $71 \%$ dari indeks musim yang diharapkan.

\subsection{Siklus}

Efek siklus didefinisikan sebagai fluktuasi bergelombang di sekitar trend. Pola siklus sulit untuk dimodelkan dalam sebuah time series karena pola ini secara tipikal tidak stabil/ tetap. Fluktuasi seperti gelombang yang naik-turun di sekitar trend jarang terulang di interval waktu yang tetap dan besarnya fluktuasi cenderung bervariasi. 


\subsection{Irregular}

Komponen irregular menunjukkan adanya keadaan yang bervariasi atau cenderung berubah pada time series setelah komponen lain dihilangkan. Komponen ini disebut residual atau error. Prediksi jumlah pengunjung perpustakaan Universitas Pattimura Ambon untuk bulan pertama sampai dengan bulan kedua belas tahun 2015 adalah dengan mengalikan keempat komponen yaitu trend, musiman, siklus dan irregular masingmasing bulan sehingga menghasilkan nilai prediksi sebagai berikut:

Januari $2015=1337,77=1337$ pengunjung perpustakaan UNPATTI

Februari $2015=2932,99=2932$ pengunjung perpustakaan UNPATTI

Maret $2015=3640,31=3640$ pengunjung perpustakaan UNPATTI

April $2015=3791,00=3791$ pengunjung perpustakaan UNPATTI

Mei $2015=4333,90=4333$ pengunjung perpustakaan UNPATTI

Juni $\quad 2015=3571,11=3571$ pengunjung perpustakaan UNPATTI

Juli 2015 $=806,00=809$ pengunjung perpustakaan UNPATTI

Agustus $2015=920,15=920$ pengunjung perpustakaan UNPATTI

September $2015=968,87=968$ pengunjung perpustakaan UNPATTI

Oktober $2015=4187,77=4187$ pengunjung perpustakaan UNPATTI

November $2015=4495,86=4495$ pengunjung perpustakaan UNPATTI

Desember $2015=2960,10=2960$ pengunjung perpustakaan UNPATTI

Untuk lebih jelasnya kita lihat Gambar plot data time series dekomposisi model multiplikatif berikut:

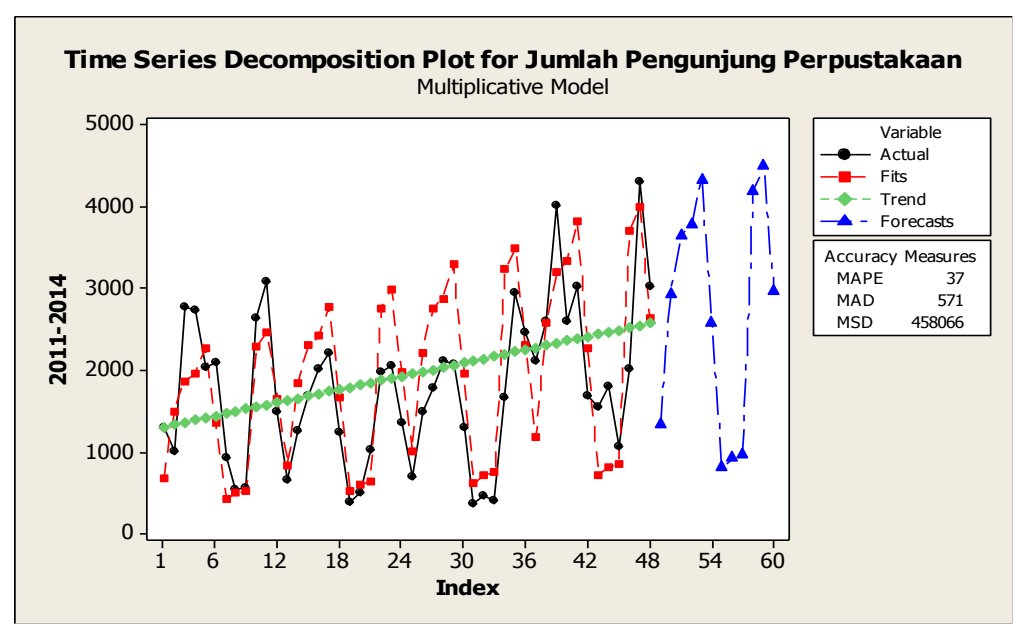

Gambar 6. Plot Data Time Series Dekomposisi Model Multiplikatif

Gambar 6 memperlihatkan hasil prediksi jumlah pengunjung di perpustakaan UNPATTI tahun 2015. Dalam grafik ditunjukkan juga bahwa terbentuk kecocokan antara komponen trend dan musiman yang berarti data aktual cukup baik. Dapat kita lihat bahwa rata-rata jumlah pengunjung meningkat pada bulan Maret-Mei dan kembali mengalami penurunan pada bulan Juni-Agustus. Peningkatan terjadi lagi pada bulan SeptemberNovember dan kembali menurun pada bulan Desember. Salah satu penyebab utama pada pola data musiman ini ialah pada bulan Maret-Mei dan September-November merupakan saat dimana kegiatan perkuliahan mahasiswa sangat aktif. Sedangkan pada bulan Juli-Agustus dan bulan Desember-Januari merupakan hari perhentian saat-saat kuliah.

Hasil prediksi pada tahun 2015 terus meningkat dibanding tahun-tahun sebelumnya. Pada kenyataannya bulan Maret-Mei dan September-November memiliki sifat musiman yang cukup tinggi sehingga prediksi pada bulan Maret-Mei dan September-November mempunyai pola data yang kuat karena hasil prediksi tahun 2015 meningkat pada ke enam bulan tersebut. 


\subsection{Uji Validasi Data Hasil Peramalan Pengunjung Perpustakaan dari Bulan Januari-Desember 2015}

Berdasarkan hasil output MINITAB diperoleh data aktual $\left(X_{i}\right)$ dan data ramalan $\left(F_{i}\right)$ disajikan dalam bentuk Tabel berikut :

Tabel 2. Uji Validasi Data Hasil Peramalan Pengunjung Perpustakaan dari Bulan Januari-Desember 2015

\begin{tabular}{|c|c|c|c|c|}
\hline Bulan & Aktual $\left(\boldsymbol{X}_{\boldsymbol{i}}\right)$ & Ramalan $\left(\boldsymbol{F}_{\boldsymbol{i}}\right)$ & $\begin{array}{c}\text { Galat/Error } \\
\boldsymbol{e}_{\boldsymbol{i}}=\boldsymbol{X}_{\boldsymbol{i}}-\boldsymbol{F}_{\boldsymbol{i}}\end{array}$ & $\boldsymbol{e}_{\boldsymbol{i}}^{\mathbf{2}}$ \\
\hline Januari & 1337 & 1337,77 & $-0,77$ & 0,5929 \\
\hline Februari & 2932 & 2932,99 & $-0,99$ & 0,9801 \\
\hline Maret & 3640 & 3640,31 & $-0,31$ & 0,0961 \\
\hline April & 3791 & 3791,00 & 0 & 0 \\
\hline Mei & 4333 & 4333,90 & -0.9 & 0,81 \\
\hline Juni & 2571 & 2571,11 & -0.11 & 0,0121 \\
\hline Juli & 806 & 806,00 & 0 & 0 \\
\hline Agustus & 920 & 920,15 & $-0,15$ & 0,0225 \\
\hline September & 968 & 968,87 & $-0,87$ & 0,7569 \\
\hline Oktober & 4187 & 4187,79 & $-0,78$ & 0,6241 \\
\hline November & 4499 & 4499,86 & $-0,87$ & 0,7396 \\
\hline Desember & 2960 & 2960,10 & -0.1 & 0,01 \\
\hline Jumlah & $\mathbf{3 2 9 4 4}$ & $\mathbf{3 2 9 4 9 , 8 5}$ & $\mathbf{- 5 , 8 5}$ & $\mathbf{4 , 6 4 4 3}$ \\
\hline
\end{tabular}

Berdasarkan Tabel 2 di menunjukkan bahwa selisih antara data aktual dan prediksi semakin besar sejak bulan Januari hingga Desember. Sehingga pada bulan Maret-Mei dan September-November memiliki sifat musiman yang cukup tinggi.

\subsection{Uji Kesesuaian Model}

Berdasarkan Tabel 3.2. diperoleh nilai pengamatan ramalan untuk $n=12$ periode waktu, maka akan terdapat 12 buah galat dan ukuran stastistik standar dapat didefinisikan sebagai berikut:

$$
\begin{aligned}
& M S E=\frac{1}{n} \sum_{t=1}^{n}\left(e_{i}\right)^{2} \\
& M S E=\frac{(-5,85)^{2}}{12} \\
& M S E=\frac{34,2225}{12} \\
& M S E=2,8519
\end{aligned}
$$

Karena nilai $M S E=2,8519$ lebih kecil dari nilai MAPE, MSD, dan MAD maka MSE (Mean Square Error) merupakan model terbaik pada analisis deret waktu. 


\section{Kesimpulan}

Berdasarkan hasil analisis data dan pembahasan yang telah dilakukan maka dapat ditarik kesimpulan sebagai berikut:

a. Model persamaan trend linier yang didapat dari hasil jumlah pengunjung Perpustakaan Universitas Pattimura Ambon dengan menggunakan data bulanan yaitu $Y_{t}=21256,25-10593,3 t$. Indikasi musiman nilai harapannya sebesar $100 \%$. Hasil yang diperoleh untuk periode Januari - Desember 2015, nilai harapannya sebagai berikut: 51\%, 111\%, 137\%, 141\%, 160\%, 94\%, 29\%, 33\%, 34\%, 147\%, 156\%, $102 \%$.

b. Jumlah pengunjung Perpustakaan Universitas Pattimura Ambon dengan menggunakan metode dekomposisi model multiplikatif dari Januari - Desember 2015 berturut-turut sebagai berikut: 1337 pengunjung, 2932 pengunjung, 3640 pengunjung, 3791 pengunjung, 4333 pengunjung, 2571 pengunjung, 806 pengunjung, 920 pengunjung, 968 pengunjung, 4187 pengunjung, 4499 pengunjung dan 2960 pengunjung. Prediksi jumlah pengunjung di Perpustakaan Universitas Pattimura Ambon terjadi kenaikan pada Bulan Mei dan November sedangkan pada Bulan Juni sampai Agustus dan Bulan Desember jumlah pengunjung mengalami penurunan.

\section{Daftar Pustaka}

[1] A. A. Taufik, "Peramalan Banyaknya Pengunjung Perpustakaan Tahun 2006 dengan Metode Dekomposisi pada Kantor Perpustakaan Kabupaten Pemalang," Semarang, 2005.

[2] N. S. Sutarno, Perpustakaan dan Masyarakat, Jakarta: Sagung Seto, 2006.

[3] P. Subagyo, Forecasting: Konsep dan Aplikasi, Yogyakarta: BPFE, 1986.

[4] A. T. Putra, "Forecasting of Sheat Demand Using Time Series Model Autoregressive Integrated Moving Average and Minimization of Forecasting Results of The Total Cost Using Wagner-Within," Jurnal Science East Borneo, 2013.

[5] S. S. C. Makridakis, D. Wheelwright and V. E. McGee, Metode dan Aplikasi Peramalan, 1st ed., vol. 1, Jakarta: Binarupa Aksara, 1993.

[6] D. Martika, "Peramalan Jumlah Pengunjung dengan Metode Dekomposisi serta Kontribusi Jumlah Pengunjung terhadap Pendapatan Objek Wisata Pantai Purwahamba Indah Tegal," Semarang, 2007.

[7] S. Assauri, Teknik dan Metode Peramalan, Jakarta: Fakultas Ekonomi UI, 1984. 